\title{
Religiousness in times of job insecurity : job demand or resource?
}

Citation for published version (APA):

Schreurs, B. H. J., Emmerik, van, I. J. H., Cuyper, De, N., Probst, T., van den Heuvel, M., \& Demerouti, E. (2014). Religiousness in times of job insecurity : job demand or resource? Career Development International, 19(7), 755-778. https://doi.org/10.1108/CDI-08-2014-0114

DOI:

10.1108/CDI-08-2014-0114

Document status and date:

Published: 01/01/2014

Document Version:

Publisher's PDF, also known as Version of Record (includes final page, issue and volume numbers)

Please check the document version of this publication:

- A submitted manuscript is the version of the article upon submission and before peer-review. There can be important differences between the submitted version and the official published version of record. People interested in the research are advised to contact the author for the final version of the publication, or visit the $\mathrm{DOI}$ to the publisher's website.

- The final author version and the galley proof are versions of the publication after peer review.

- The final published version features the final layout of the paper including the volume, issue and page numbers.

Link to publication

\section{General rights}

Copyright and moral rights for the publications made accessible in the public portal are retained by the authors and/or other copyright owners and it is a condition of accessing publications that users recognise and abide by the legal requirements associated with these rights.

- Users may download and print one copy of any publication from the public portal for the purpose of private study or research.

- You may not further distribute the material or use it for any profit-making activity or commercial gain

- You may freely distribute the URL identifying the publication in the public portal.

If the publication is distributed under the terms of Article 25fa of the Dutch Copyright Act, indicated by the "Taverne" license above, please follow below link for the End User Agreement:

www.tue.nl/taverne

Take down policy

If you believe that this document breaches copyright please contact us at:

openaccess@tue.nl

providing details and we will investigate your claim. 


\title{
Religiousness in times of job insecurity: job demand or resource?
}

\author{
Bert Schreurs and Hetty van Emmerik \\ Department of Organization \& Strategy, \\ Maastricht University School of Business and Economics, Maastricht, \\ The Netherlands \\ Nele De Cuyper \\ Department of Occupational \& Organisational Psychology and \\ Professional Learning, University of Leuven (KU Leuven), Leuven, Belgium \\ Tahira Probst \\ Department of Psychology, Washington State University Vancouver, \\ Vancouver, Washington, USA \\ Machteld van den Heuvel \\ Faculty of Social and Behavioural Sciences, University of Amsterdam, \\ Amsterdam, The Netherlands, and \\ Eva Demerouti \\ Department of Industrial Engineering \& Innovation Sciences, \\ Eindhoven University of Technology, Eindhoven, The Netherlands
}

\begin{abstract}
Purpose - Departing from the job demands resources model, the purpose of this paper is to investigate whether religion, defined as strength of religious faith, can be viewed as resource or as demand. More specifically, the authors addressed the question as to how job insecurity and religion interact in predicting burnout and change-oriented behavior.

Design/methodology/approach - The authors conducted moderated structural equation modeling on survey data from a sample of 238 employees confronted with organizational change.

Findings - Results were largely consistent with the "religion as a demand" hypothesis: religion exacerbated rather than buffered the negative effects of job insecurity, so that the adverse impact of job insecurity was stronger for highly religious employees than for employees with low levels of religiousness. Religious employees appear to experience more strain when faced with the possibility of job loss.

Originality/value - The results of this study challenge and extend existing knowledge on the role of religion in coping with life stressors. The dominant view has been that religion is beneficial in coping with major stressors. The results of this study, however, suggest otherwise: religion had an exacerbating rather than a buffering effect on the relationship between job insecurity and outcomes. Keywords Religion, Burnout, Job insecurity, Organizational change, Religiosity

Paper type Research paper
\end{abstract}

If anyone is not willing to work, let him not eat (Thessalonians 3:10).

Never should anyone of you think that $d u^{\prime} a a^{\prime}$ (supplication) for sustenance without work will avail him, for heaven never rains gold nor silver (The Book of Provision, Chapter 1).

During the last few decades, employees in many countries have increasingly been exposed to major organizational changes (e.g. closures, restructuring, mergers, and

Religiousness in times of job insecurity

755

Received 25 August 2014

Revised 29 August 2014 Accepted 4 September 2014

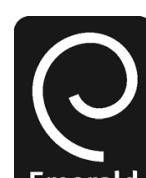

Emerald

Career Development International Vol. 19 No. 7, 2014

(C) Emerald Group Publishing Limited 1362-0436 DOI 10.1108/CDI-08-2014-0114 
CDI

19,7

756 acquisitions), often accompanied by large-scale layoffs. The recent financial crisis undoubtedly aggravated the frequency and severity of changes, thereby provoking increased feelings of job insecurity among employees. The present study examines the role and impact of religion in the workplace during times of uncertainty and how religion may affect employees' outcomes in response to job insecurity.

Job insecurity - an individual's overall concern about the continued existence of, or the threat to, his or her job (Bernhard-Oettel et al., 2011) - has been recognized as one of the major stressors existing in the work environment, leading to a laundry list of disadvantageous outcomes, both for the individual and the organization (Cheng and Chan, 2008; Sverke et al., 2002). From an individual perspective, job insecurity has been found to relate negatively to mental or psychological well-being, and to physical health indicators (Ferrie et al., 2002; Schreurs et al., 2010). From an organizational perspective, job insecurity can be costly in terms of increased employee turnover intentions (Sverke et al., 2002), lower employee creativity (Probst et al., 2007), lower job satisfaction (Zheng et al., 2014), increased injury rates (Probst et al., 2013) as well as reduced commitment to organizational change initiatives (Kalyal et al., 2010).

In the present study, we investigate both individually and organizationally relevant potential outcomes of job insecurity. From the former category, we considered the relationship between job insecurity and employee burnout (i.e. emotional exhaustion, cynicism). From the latter category, we examined how the perception of job insecurity was related to change-oriented behaviors (i.e. personal initiative, willingness to change). As noted above, we were particularly interested in determining the extent to which religion might moderate these relationships.

Given the adverse outcomes of job insecurity, scholars have spent a great deal of effort trying to identify factors that may cushion its effects. Among the most successful stress-buffering factors are personality dispositions, such as internal locus of control (Näswall et al., 2005), and environmental variables, including social support (Lim, 1996), participatory decision making (Probst, 2005), job control (Schreurs et al., 2010) and personal resources, such as employability (Berntson et al., 2010). To date, there has been no empirical research examining the role of religion in the appraisal of and response to job insecurity, despite repeated calls for investigation into the relationship between job stressors and religion (Probst and Strand, 2010; Zellars et al., 2003). We believe this to be an important omission given the continued importance of religion in society (Argyle, 2000; Emmons and Paloutzian, 2003), and perhaps more importantly, existing findings on the role of religion in coping with negative life events. Religious beliefs may help people to make sense of their situation and to enable them to better integrate changes or potential threats (i.e. job insecurity) into their lives (Pargament et al., 1998; Schaefer et al., 2008).

This paper focusses on the role of religion and how religion may be an important construct in determining employees' outcomes in times of uncertainty and insecurity. We will consider two contrasting lines of reasoning. First, following a less ambiguous line of reasoning, we will focus on how religiousness - the strength of one's religious faith - can be expected to mitigate the negative effects of job insecurity (i.e. the stressbuffering hypothesis). However, perhaps counterintuitively, we will also consider evidence suggesting that religiousness may exacerbate the negative effects of job insecurity (stress-exacerbating hypothesis) by pointing at the central role of work in the life of religious people and viewing job insecurity as an identity-relevant stressor, especially for religious people. To examine the plausibility of both lines of reasoning, we present the results from a field study examining the extent to which job insecurity 
and religiousness interact in predicting employees' outcomes in terms of employee burnout and change-oriented behaviors.

\section{Job insecurity}

Researchers have arrived at the conclusion that job insecurity is a cause for concern: job insecurity is a work stressor, hence causing strain, for example in the form of suboptimal health or an increased risk of burnout. The job insecurity-strain process is mediated to a great extent by the worker's perceived lack of control (Vander Elst et al., 2011). Indeed, uncontrollability is core to the experience of job insecurity: employees do not know what will happen in the future (De Witte, 1999; Jacobson, 1991; Sverke et al., 2002), be it job loss or continued employment. Furthermore, studies in different areas of psychology, experimental and field studies alike, have demonstrated a relationship between uncontrollability and strain (e.g. Steptoe et al., 1999).

There is abundant evidence for the idea that job insecurity is associated with poorer health and well-being (for meta-analyses, see Cheng and Chan, 2008; Sverke et al., 2002). Job insecurity relates to, for example, psychological distress, anxiety and depression (Roskies et al., 1993), psychosomatic complaints (Zapata-Phelan et al., 2009), and with objective indicators of poor health, such as medically certified sickness absence (Davy et al., 1997) and use of medical services (Catalano et al., 1986). Furthermore, Ferrie and colleagues (Ferrie et al., 2002, 2005) showed that job insecurity also has adverse physiological outcomes in the long term, such as increased blood pressure and body mass index.

Of particular importance in the context of this study are findings that attest to positive relationships between job insecurity and dimensions of burnout. Burnout is often defined as a state of exhaustion in which workers are cynical about the value of their occupation and doubtful of their capacity to perform (Maslach et al., 2001). The core of burnout consists of emotional exhaustion (i.e. the depletion of mental resources) and cynicism (i.e. an indifferent and detached attitude toward one's job) (Schaufeli and Taris, 2005), both of which have been repeatedly shown to be positively associated with job insecurity (e.g. Bosman et al., 2005; Boswell et al., in press; De Cuyper et al., 2012; Dekker and Schaufeli, 1995; Westman et al., 2001).

Job insecurity and its accompanying feelings of uncontrollability may also leave the worker little choice but to withdraw from the situation, not only emotionally but also behaviorally (Jordan et al., 2002). Emotional withdrawal has received a fair deal of research attention. For example, meta-analytic results from dozens of studies have found consistent negative relationships between job insecurity and affective organizational commitment, and positive relationships with turnover intentions (Cheng and Chan, 2008; Sverke et al., 2002). In contrast, behavioral forms of withdrawal have received comparatively little research attention (Reisel et al., 2007; Staufenbiel and König, 2010).

In the current study, we contribute to the scant literature in this area by testing the proposition that job insecure employees, because of their inclination to withdraw from the situation, are less likely to engage in change-oriented behaviors. Change-oriented behavior is defined as "voluntary acts of creativity and innovation designed to improve one's task or the organization's performance" (Podsakoff et al., 2000). Examples of such behavior are taking personal initiative and complying with organizational changes (Choi, 2007). Evidence in support of the relation between job insecurity and changeoriented behavior is provided by studies showing that job insecure employees are less likely to perform tasks beyond their formal tasks descriptions, such as taking new
Religiousness in times of job insecurity 
CDI

19,7

758 initiatives (Feather and Rauter, 2004; King, 2000) and demonstrate a greater inability to identify creative or novel solutions to posed problems (Probst et al., 2007). There is also some support for a moderate positive relationship between job insecurity and resistance to change, as evidenced in studies by Rosenblatt and Ruvio (1996) and Kalyal et al. (2010). These findings align with threat rigidity theory (Staw et al., 1981), stating that individuals tend to emit dominant, well-learned or habituated responses in threat situations. Collectively, the available evidence suggests that insecure employment situations give rise to lack of flexibility and may prevent employees from engaging in change-oriented OCBs.

\section{Religion: resource or demand?}

As noted earlier, in addition to extending the literature on job insecurity by considering behavioral forms of withdrawal, the primary purpose and contribution of the current study was to examine whether religion may represent a factor that protects individuals from or intensifies the detrimental effects of job insecurity on burnout and change-oriented behaviors.

A number of different definitions for religion have been proposed, each of which has emphasized different features, and often resulting in considerable confusion among researchers as to what exactly constitutes the central characteristics of the construct (Zinnbauer et al., 1997). Definitions of religion range from organized practices that define religious denominations, sects, and traditions (Probst and Strand, 2010), including adherence to beliefs - personal or institutionalized - in a divine being or a higher power; and to rituals or other behaviors focussed on the higher power, or pragmatically to referring to religion as an overarching view of the world and thus to a complete way of life (Smelser and Baltes, 2001). For the purpose of this study, we use the definition of religion provided by Plante et al. (2002), namely: strength of religious faith. We use this definition because it does not assume that the person adheres to a particular religious denomination or affiliation.

Due to the broad nature and variety of definitions, scholars are increasingly recognizing the importance of distinguishing between institutionalized and personal beliefs and practices, i.e. between religiousness and spirituality. The former typically refers to formalized beliefs and social structures and practices (institutional religion), whereas the latter relates to the personal search for meaning, transcendence, and connectedness (Pargament, 1999; Zinnbauer et al., 1999). In this respect, Pargament (2002) states that "religion is a richer, more complex process than psychologists have imagined, one that has the potential both to help and to harm" (p. 168). This brings us to our central research question - whether, and to what extent, religion - defined as strength of religious faith - is helpful or harmful in dealing with job insecurity. Below we will elaborate on how religion can be viewed as a protective factor, i.e. resource or as a straining factor, i.e. demand.

According to the job demands-resources (JD-R; Demerouti et al., 2001) model of job stress, there are numerous factors associated with any job that may increase or decrease the likelihood of experiencing job stress. These factors can be physical, psychological, social, or organizational in nature and can be characterized as either demands or resources. Whereas demands require sustained psychological and/or physical effort (e.g. time pressure), resources are "functional in achieving work goals; reduce job demands and the associated physiological and psychological cost; stimulate personal growth, learning, and development” (Demerouti et al., 2001, p. 501). Based on 
theoretical and empirical evidence, we contend that religion could be potentially characterized as both a demand and a resource. Depending on the function of religion for the individual, this may lead to religion acting as a buffering or as an exacerbating force in employee reactions to job insecurity.
Religiousness in times of job insecurity

\section{Religion as a resource: a meaning-making perspective}

Probst and Strand (2010) propose that religion may buffer the negative consequences of job insecurity, such that job insecurity has less negative effects in terms of well-being and performance for high than for low religious employees. Specifically, they argue that religion could be considered an "available resource" or source of strength to draw upon. This resource could function in one of two ways. On the one hand, Emmons (2000) suggested that religion may represent a form of intelligence (i.e. a set of skills and abilities) that assists in the attainment of goals and daily problem solving. Thus, highly religious individuals may be more capable of dealing with potentially stressful organizational events (e.g. restructuring, mergers, layoffs) that engender a sense of job insecurity. On the other hand, religion may serve to protect one's sense of self identity independent of one's job. Some researchers have argued that individuals react negatively to organizational change to the extent that they appraise the change as threatening to their sense of self (Wiesenfeld et al., 2001). Individuals who define themselves less in terms of their work role and more in terms of their religion may be less likely to appraise such organizational changes as threatening to their sense of self. As Probst and Strand (2010, p. 144) argue, "according to most religious faiths and spiritual teachings, individual worth and value are not a function of wealth or derived from one's job or social position. Rather, all individuals are seen as worthy and having inherent value." Therefore, perceptions of job insecurity may be appraised as less stressful by individuals whose sense of self is defined by their religion more than by their job.

This notion is also supported by meaning-making theory in the context of stress and coping (Park, 2005; Park and Folkman, 1997), which is an extended and more fine-grained version of the well-known transactional stress and coping theory (Lazarus, 1966; Lazarus and Folkman, 1984). Meaning-making theory explains how religion - as a comprehensive worldview and primary meaning making system - can help in coping with major stressors by transforming the meaning of stressful experiences through cognitive adaptation.

According to meaning-making theory, the same objective situation (i.e. potential job loss) is likely to be appraised differently by highly religious individuals and those who are less religious. For instance, religious people may appraise their situation as less harmful or threatening, for example by viewing the potentially stressful organizational event (e.g. restructuring, mergers, layoffs) as part of God's plan (Mickley et al., 1998), or as a spiritual opportunity (Pargament, 1997). Furthermore, religious individuals may perceive themselves as more capable of dealing with these events, because they feel supported by God or because of their highly developed sense of spirituality (Dezutter et al., 2010; Probst and Strand, 2010). Finally, religion may also provide specific tools, including prayer, support from clergy or congregation members, meditation, and spiritual reflection, to facilitate coping (Dezutter et al., 2010). As a result of these (re)-appraisal processes, highly religious individuals facing potential job loss can be assumed to experience lower levels of strain, in terms of burnout and change-oriented behaviors, than their less devout colleagues. 
CDI

19,7

760
Although no research to date has specifically examined the role of religion in coping with job insecurity, several studies do provide empirical evidence for the stressbuffering nature of religion in coping with stressful life events, including living in a deteriorated neighborhood (Krause, 1998), lack of sexual gratification (Wallin and Clark, 1964), substance use and abuse (Kendler et al., 1997), and loss of a child or relative (Park and Cohen, 1993). Thus, religion seems to decrease some negative behaviors direct and indirectly by giving strength and comfort which may translate in better health outcomes and well-being. In this way religion may make the lives of people less stressful. Further, it is possible that more involvement in religious organizations decreases undesirable behaviors and feelings by providing people with a belief system that guides their decisions and behaviors.

Based on the theoretical arguments presented above and the empirical evidence from other stress domains, we predict that (the stress-buffering hypothesis):

H1a. Religion will buffer the positive relationship between job insecurity and burnout, such that the effect of job insecurity on burnout is less pronounced for high than for low religious employees.

H2a. Religion will buffer the negative relationship between job insecurity and change-oriented behavior, such that the effect of job insecurity on changeoriented behavior is less pronounced for high than for low religious employees.

\section{Religion as a demand: might religion make a bad situation worse?}

On the other hand, theory and research also suggest that a heightened sense of religiousness may have the potential to exacerbate the outcomes associated with job insecurity. We argue that, in this case, religion may operate as a demand. Zinnbauer et al. (1999) suggested that some individuals view their work as a sacred vocation, and therefore, are likely to view their employment within an organization in a different light than individuals who see their work as a means to pay one's bills. While viewing one's job in this light may give added meaning to work (i.e. it is an extension of one's life purpose), it may also create added pressure or demands. Specifically, it may make individuals even more vulnerable to the negative effects of insecurity insofar as individuals consider their work to be a sacred vocation and central to their self-concept. In this situation, a potential threat of job loss means more than a loss of income; it also is a loss of self and sacred purpose. For instance, in Jahoda's (1982) latent deprivation model, threat of unemployment also emphasizes the differential value of losing important (financial, social, and societal) resources. Thus, whether religion plays a buffering or exacerbating role may be determined by the extent to which religion fosters a sense of worth independent of one's work (i.e. a resource) vs creates a sense of self-worth that is intertwined with one's vocation (i.e. a demand).

One can also draw on the concept of "identity-relevant stressors" (Thoits, 1991). Thoits defines identities and identity-relevant experiences as "individuals" conceptions of themselves in terms of the social roles that they enact (e.g. spouse, parent, worker, churchgoer, friend). An identity-relevant experience is one that threatens or, alternatively, enhances an identity that the individual values highly" (p. 101). Within the context of a religious belief system where work plays a central role in life (e.g. the Protestant work ethic), work will be a very salient social role. When experiencing job insecurity, the fear of losing one's job may seriously undermine an individual's most salient role-identities and be an identity-threatening stressor. In this way, religion has 
the potential to make a bad situation worse since job insecurity acts as an identityrelevant stressor.

Again, there have not been any empirical studies to directly test the role of religion in moderating outcomes of job insecurity. However, there is evidence that employees who are more invested and involved in their jobs are more negatively affected by job insecurity. Job involvement is greater when work plays an increasingly central role in an employee's life, as would be expected when an individual views their job as a sacred vocation. Probst (2000) found that highly involved employees reported more negative job attitudes, more health problems, and a higher level of psychological distress in response to perceived job insecurity compared to their less involved counterparts.

Based on the theoretical argument that religion may act as a demand and the accompanying empirical evidence, we propose a competing alternative to $\mathrm{HI}$ and predict that (the stress-exacerbating hypothesis):

H1b. Religiousness will exacerbate the positive relationship between job insecurity and burnout, such that the effect of job insecurity on burnout is more pronounced for high than for low religious employees.

H2b. Religiousness will exacerbate the negative relationship between job insecurity and change-oriented behavior, such that the effect of job insecurity on change-oriented behavior is more pronounced for high than for low religious employees.

\section{Method}

\section{Procedure and participants}

The sample used for this study consisted of 238 workers employed in a variety of sectors. Data were collected via two different approaches. First, 200 written surveys were distributed in-person to health care workers employed in a health care institution located in the "Bible Belt" in the center of the Netherlands. The Bible Belt is a stretch of land inhabited mainly by conservative Protestants. At the time of the study, the health care institution was going through substantial changes, including the resignation of a number of personnel and the introduction of a new working methodology. The employees received a cover letter, which described the aim of the study in very general terms (to avoid socially desirable answers), and emphasized the anonymity and confidentiality of the data. Employees were requested to fill out the survey that accompanied the letter, where necessary in the presence of a research assistant, who was available to answer questions and collected the surveys when complete. This approach was taken because the majority of employees were lower-educated and had very little experience with answering surveys. Usable surveys were obtained from 58 individuals (response rate $=29$ percent).

The remaining 180 respondents were recruited by three master students using a snowball sampling technique. Students were instructed to identify employees confronted with organizational change and invite them to participate. Those so identified were asked to identify others, and so on, for the purpose of obtaining a nonprobability sample (Goodman, 1961). Furthermore, in the instructions to the invitees it was highlighted that they should only fill out the questionnaire if their company was currently undergoing significant changes, such as mergers and acquisitions, right/downsizing, major restructuring, and changes in management. The snowball sampling strategy is particularly effective in locating members of special and hard to reach populations where
Religiousness in times of job insecurity

761 
CDI

19,7

762

the focus of the study is on a sensitive issue (Faugier and Sargeant, 1997). Both job insecurity and religiousness qualify as sensitive issues; the former because job insecurity is typically associated with a strong critical stance toward the organization; the latter because religiousness belongs to the private sphere. Snowball sampling has been successfully used in previous research on organizational change (van den Heuvel et al., 2009). No response rate can be provided with this sampling strategy.

Table I summarizes the sample's and subsamples' characteristics. Most of the respondents were female. More than half of the respondents had higher education and were full-time employed. About one in three had less than two-year tenure. Roughly 60 percent was employed in the public sector. About as many operational staff as middle/ senior management participated. Approximately two in three participants was married or lived together with a partner. The respondents' mean age was 39 years. On average,

\begin{tabular}{|c|c|c|c|c|}
\hline Demographic & Total $(N=238)$ & $\begin{array}{l}\text { (1) Health care } \\
\text { institution }^{\mathrm{a}}\end{array}$ & (2) Snowball ${ }^{\mathrm{b}}$ & $\begin{array}{c}\text { Differences } \\
\left(\chi^{2} / t\right)\end{array}$ \\
\hline \multicolumn{5}{|l|}{ Gender (\%) } \\
\hline Men & 35.68 & 10.34 & 44.38 & \\
\hline Women & 64.32 & 89.66 & 55.62 & $25.09 * * *$ \\
\hline \multicolumn{5}{|l|}{ Education (\%) } \\
\hline Low/middle educational level & 43.61 & 84.48 & 29.59 & \\
\hline \multicolumn{5}{|l|}{ Type of contract (\%) } \\
\hline Permanent workers & 72.25 & 89.66 & 66.27 & \\
\hline Fixed-term workers & 27.75 & 10.34 & 33.73 & 13.50 **** \\
\hline \multicolumn{5}{|l|}{ Employment (\%) } \\
\hline Full-time & 56.19 & 12.28 & 71.01 & \\
\hline \multicolumn{4}{|l|}{ Job type (\%) } & $63.85^{* * *}$ \\
\hline Operational staff & 50.22 & 81.03 & 39.52 & \\
\hline $\begin{array}{l}\text { Middle/senior management } \\
\text { Sector (\%) }\end{array}$ & 49.78 & \multicolumn{2}{|c|}{ Sector (\%) } & $31.45^{* * * *}$ \\
\hline Public & 57.71 & 0 & 77.51 & \\
\hline Private & 42.29 & 100 & 22.49 & $129.12^{* * *}$ \\
\hline \multicolumn{5}{|l|}{ Religious affiliation (\%) } \\
\hline None & 44.25 & 31.58 & 48.52 & \\
\hline Roman Catholicism & 32.74 & 21.05 & 36.69 & \\
\hline Protestantism & 15.92 & 40.36 & 7.69 & \\
\hline Other & 7.07 & 7.02 & 7.1 & $32.97 * * *$ \\
\hline \multicolumn{5}{|l|}{ Marital status (\%) } \\
\hline Single & 25.11 & 17.24 & 27.81 & \\
\hline Married/cohabitation & 74.89 & 82.76 & 72.19 & $42.02^{* * * *}$ \\
\hline \multicolumn{5}{|l|}{ Organizational tenure } \\
\hline$<2$ years & 29.20 & 5.26 & 37.28 & \\
\hline $2-5$ years & 16.37 & 8.77 & 18.93 & \\
\hline $5-10$ years & 21.68 & 35.09 & 17.16 & \\
\hline $10-20$ years & 17.26 & 29.82 & 13.02 & \\
\hline$>20$ years & 15.49 & 21.05 & 13.61 & $36.86^{* * * *}$ \\
\hline \multicolumn{5}{|l|}{$M(\mathrm{SD})$} \\
\hline Age & 38.86 (12.55) & $46.72(11.49)$ & 36.17 (11.77) & $5.93 * * *$ \\
\hline Number of children & $0.98(1.21)$ & $1.83(1.31)$ & $0.69(1.03)$ & $6.73^{* * *}$ \\
\hline \multicolumn{5}{|c|}{ Notes: ${ }^{\mathrm{a}} n=58 ;{ }^{\mathrm{b}} n=180 ;{ }^{* * *} p<0.001$} \\
\hline
\end{tabular}

Table I.

Sample demographics 
respondents had one child. The share of religiously affiliated and non-affiliated respondents was about equal. Respondents were employed in a broad range of job positions as appears from employees' job names, including "sales support manager," "office manager," "nurse," "police officer," "entrepreneur," and many others.

The health care and the snowball sample differ significantly in their demographics. Relative to the snowball sample, the health care sample consisted of more women, more operational staff, and more employees with a permanent and a part-time contract. Respondents from the health care sample were older and more tenured, and had more children than employees from the snowball sample. The share of married/cohabitating respondents was higher in the health care sample. Compared to the health care sample, respondents from the snowball sample were higher educated and less likely to be religiously affiliated. In the snowball sample, more than three in four respondents were employed in the public sector. Despite these differences, both samples were combined for further analysis to increase sample size. Increasing sample size increases the power and yields more precise estimates (MacCallum et al., 1996). To account for sample differences, sample was controlled for in all analyses (see below).

\section{Measures}

Job insecurity. Job insecurity was measured using the five-item scale developed by De Witte (2000). A sample item is: "Chances are I will soon lose my job.” Respondents were asked to rate these items on a five-point Likert type scale $(1=$ strongly disagree, $5=$ strongly agree). Cronbach's $\alpha$ was $0.68(M=2.56$; $\mathrm{SD}=1.06)$.

Religiousness. Religiousness was measured using the Santa Clara Strength of Religious Faith Questionnaire (SCSRFQ, Plante and Boccaccini, 1997). The SCSRFQ has been developed to specifically measure strength of religious faith, without assuming that the individual is of a specific religious affiliation. The SCSRFQ consists of ten items. A sample item is "My faith impacts many of my decisions." Answers were given on a four-point Likert scale $(1=$ not at all characteristic, $4=$ totally characteristic). Cronbach's $\alpha$ was $0.97(M=1.81 ; \mathrm{SD}=0.85)$.

Burnout. We measured the core dimensions of burnout, namely exhaustion and cynicism (Maslach et al., 2001). Exhaustion was measured using the corresponding scale of the Maslach Burnout Inventory - General Survey (Schaufeli et al., 1996), which includes five items. A sample item is "I feel emotionally drained from my work." Answers were given on a seven-point Likert scale $(0=$ never, $6=$ every day). Cronbach's $\alpha$ was $0.87(M=1.64$; $\mathrm{SD}=1.11)$. Cynicism was measured using the corresponding scale of the Maslach Burnout Inventory - General Survey (1986), which included four items. A sample item is "I have become more cynical about whether my work contributes anything." Answers were given on a seven-point Likert scale $(0=$ never, $6=$ every day). Cronbach's $\alpha$ was $0.78(M=1.45$; $\mathrm{SD}=1.04)$.

Change-oriented behavior. We used two indicators of change-oriented behavior: personal initiative and willingness to change (Choi, 2007). Personal initiative was assessed using the seven-item scale developed by Frese et al. (1997). A sample item is "I actively attack problems." Participants were asked to indicate the extent to which each statement characterizes them on a five-point scale $(1=$ not at all characteristic, $5=$ totally characteristic). Cronbach's $\alpha$ was $0.86(M=3.69 ; \mathrm{SD}=0.62)$. Willingness to change was assessed using an adapted version of Metselaar's (1997) four-item scale. The items relate to employees' intention to invest time and effort to support the implementation of the change. A sample item is "I'm willing to convince my colleagues

\section{Religiousness in times of job insecurity}

763 
CDI

19,7

764 of the benefits the change will bring." Participants were asked to indicate the extent to which each statement characterizes them on a five-point scale $(1=$ not at all characteristic, $5=$ totally characteristic). Cronbach's $\alpha$ was $0.91(M=3.73 ; \mathrm{SD}=0.80)$.

Control variables. Age (in years), organizational tenure $(1=<2$ years, $2=2-5$ years, $3=5-10$ years, $4=10-20$ years, $5=>20$ years), gender $(0=$ male, $1=$ female), educational level $(0=$ lower/middle educational level, $1=$ higher educational level), sample $(0=$ health care institution, $1=$ snowball), and type of contract $(0=$ fixed term contract, $1=$ permanent contract) were included as control variables in all the analyses because of their potential link with the independent and the outcome variables considered in this study (e.g. Brewer and Shapard, 2004; De Cuyper and De Witte, 2007; Ellison and Levin, 1998). To rule out the possibility that the observed relationships of interest are due to whether someone identifies with a particular religious denomination, we also controlled for religious affiliation. Religious affiliation was measured by a single item with fixed response categories. The item was: "What is your religion?" Respondents could select one of the following options: "none," "Protestant," "Roman Catholic," and "other" (including "Islam," "Judaism," "Hinduism," and "Buddhism”). We dummy-coded religious affiliation so that 0 represented non-affiliated respondents and 1 represented affiliated respondents.

\section{Strategy of analysis}

Prior to hypotheses testing, we compared various measurement models via confirmatory factor analysis (Stata 12.0). First, we tested a measurement model including six latent variables: job insecurity, religious faith, emotional exhaustion, cynicism, personal initiative, and willingness to change. Scale items were used as indicators of the latent factors. The latent factors were allowed to correlate and all error co-variances were constrained to zero. Next, to examine the potential for common method bias, we tested two models: Harman's single factor model (in which all items loaded on one factor) and a latent common method factor model (in which all items loaded on both their expected factors and a latent common method factor) (Podsakoff et al., 2003).

The hypotheses were tested with moderated structural equation modeling (MSEM)[1]. Following the procedure proposed by Mathieu et al. (1992), as described in Cortina et al. (2001), we tested a structural model that, in addition to the control variables (age, gender, organizational tenure, religious affiliation, educational level, sample, and type of contract), included three exogenous factors (i.e. job insecurity, religious faith, and their interaction) and two endogenous factors (burnout and change-oriented behavior). Each exogenous factor had only one indicator, namely the standardized scale score of the respective factor. The endogenous factors had two indicators each: The scale scores of emotional exhaustion and cynicism for burnout and the scale scores of personal initiative and willingness to change for change-oriented behavior. The model tested included direct paths from the three exogenous factors to the two endogenous factors. The paths from the latent exogenous factors to their indicators were fixed using the square roots of the scale reliabilities, while the error variances of each indicator were set equal to the product of their variances and one minus their reliabilities. The reliability of the interaction term was calculated according to the formula provided by Bornstedt and Marwell (1978), as described in Cortina et al. (2001). Job insecurity and religious faith were allowed to correlate, while the correlation between job insecurity/religious faith and the interaction term was fixed to zero. Finally, the residual errors of the two outcome variables were allowed to correlate. 
A significant interaction effect is evident when the path coefficient from the interaction term to the endogenous factors is statistically significant. The final step is to test the model with and without the path from the interaction term to endogenous factors, thus allowing a $\chi^{2}$ test of the differences in fit between the models.

The fit of the models was assessed with the $\chi^{2}$ statistic, the root mean square error of approximation (RMSEA), standardized root mean square residual (SRMR), comparative fit index (CFI) and Tucker Lewis index (TLI). For RMSEA and SRMR, values $<0.05$ represent good fit, values of $0.05-0.08$ represent moderate fit, and values of 0.08-0.10 represent adequate fit (Browne and Cudeck, 1993). For CFI and TLI, values of 0.90 are acceptable, whereas values of 0.95 or higher are indicative of excellent fit (Hu and Bentler, 1999).

\section{Results}

Descriptive statistics

Table II shows the intercorrelations of the scales included in the analyses. As can be seen from the table, job insecurity was positively associated with emotional exhaustion and cynicism, and negatively with personal initiative and willingness to change. Job insecurity was not significantly related to the presumed moderator, religious faith. Interestingly, religious affiliation and strength of religious faith demonstrated a moderately large correlation (0.56), suggesting that these two constructs share over 30 percent variance. Because religion affiliation was entered as a control variable in subsequent analyses, this allowed us to test the unique effects of religiousness (independent of religious affiliation).

\section{Measurement models}

The six-correlated-factors model provided an adequate fit to the data (cf. Table III). All items loaded significantly on the intended latent factors. The fit of Harman's single factor model was significantly worse than the fit of the six-correlated-factors model $\left(\Delta \chi^{2}(16)=2,454.40, p<0.001\right)$. Also, the fit of the latent common method factor model was slightly worse than the fit of the six-correlated-factors model $\left(\Delta \chi^{2}\right.$ $(34)=14.06, \mathrm{~ns})$. These results collectively suggest that common method bias was not a serious problem in this study.

\section{Test of hypotheses}

The hypothesized structural equation model provided a good fit to the data (cf. Table III). Job insecurity was positively related to burnout $(\beta=0.35, p<0.001)$ and negatively related to change-oriented behavior $(\beta=-0.38, p<0.001)$. Gender $(\beta=0.20, p<0.05)$, and type of contract $(\beta=0.21, p<0.05)$ were positively related to change-oriented behavior. Organizational tenure was negatively related to change-oriented behavior $(\beta=-0.38, p<0.001)$ and positively to burnout $(\beta=0.25, p<0.05)$. Religious faith did not show a significant relationship with either burnout or change-oriented behavior. However, as hypothesized, job insecurity and religious faith significantly interacted in the prediction of burnout $(\beta=0.20, p<0.05)$, and change-oriented behavior $(\beta=-0.18, p<0.05)$.

In a next step, the model was tested without the path from the latent interaction term to burnout. The constrained model showed a worse fit than the hypothesized model $\left(\Delta \chi^{2}(1)=4.52, p<0.05\right)$. Similarly, elimination of the path from the latent interaction term to change-oriented behavior did produce a slightly worse fit to the data than the 


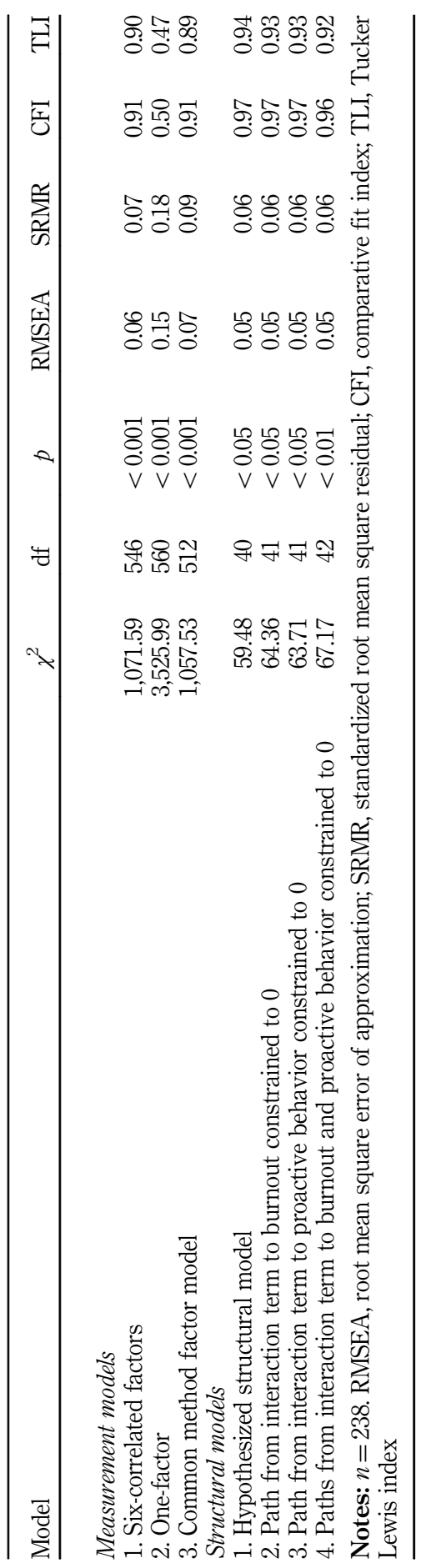

Religiousness in times of job insecurity

767

Table III.

Goodness-of-fit indices (maximum likelihood estimates) for the measurement and structural models 
CDI

19,7

768

hypothesized model $\left(\Delta \chi^{2}(1)=3.87, p<0.05\right)$. Not surprisingly, elimination of both paths - to burnout and to change-oriented behavior - yielded a worse fit compared to the hypothesized model $\left(\Delta \chi^{2}(2)=7.33, p<0.05\right)$. All resulting relationships (except for the control variables) are graphically displayed in Figure 1.

We plotted the job insecurity $\times$ religious faith interaction at three levels of religious faith (i.e. +1 SD, 0 , and -1 SD; Bauer and Curran, 2005), and conducted a simple slope test to examine the nature of the interaction. The interactions are graphically represented in Figures 2 and 3. A visual inspection of the graphs and a simple slopes test showed that at low levels of religious faith, job insecurity was unrelated to burnout $(t=1.18, \mathrm{~ns})$. For average and highly religious employees, job insecurity was positively

Figure 1.

Standardized coefficients of main variables
Figure 2.

Interactive effects of job insecurity and religiousness on burnout

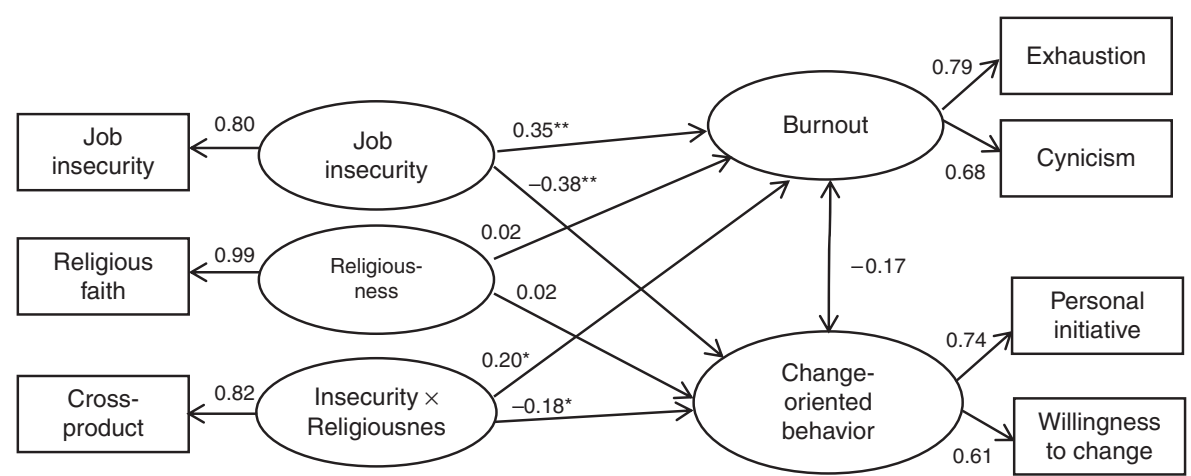

Notes: $n=238,{ }^{*} p<0.05 ;{ }^{* *} p<0.01$

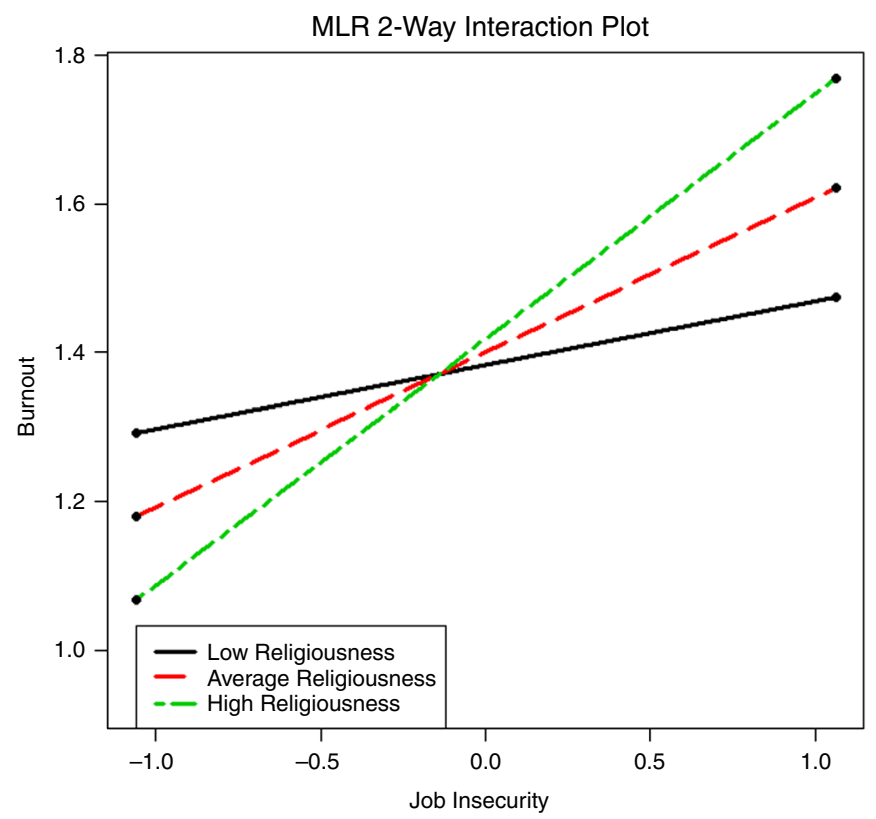




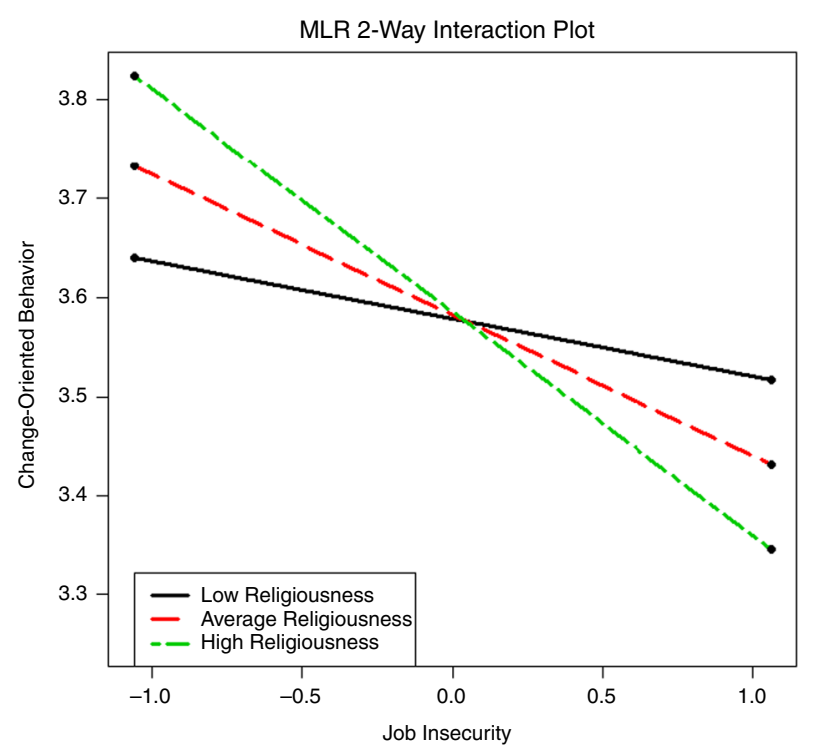

\section{Religiousness in times of job insecurity}

769

Figure 3. Interactive effects of job insecurity and religiousness on change-oriented behavior

related to burnout $(t=3.98, p<0.001$ and $t=4.56, p<0.001$ ), supporting $H 1 b$ rather than $H 1 a$. Similarly, for not very religious employees, there is no relation between job insecurity and change-oriented behavior $(t=-1.11$, ns). For average and highly religious employees, job insecurity was negatively related to change-oriented behavior $(t=-3.81, p<0.001$ and $t=-4.39, p<0.001)$, supporting $H 2 b$ rather than $H 2 a$. The model explained 21 percent of the variance in burnout and 26 percent in change-oriented behavior.

\section{Additional analysis}

We conducted an additional MSEM analysis to examine whether the effect of religious faith is different among those who have at least minimal levels of religious faith, excluding all cases with the lowest score on religious faith $(n=82)$. Results were very similar to what we found in the total sample, except for the following:

(1) job insecurity was unrelated to burnout $(\beta=0.19$, ns);

(2) type of contract was unrelated to change-oriented behavior $(\beta=0.19$, ns); and

(3) job insecurity and religious faith did not significantly interact in their prediction of change-oriented behavior $(\beta=-0.13, \mathrm{~ns})$.

Hence, in a sample of employees with least minimal levels of religious faith, the negative effect of job insecurity on change-oriented behavior did not depend on the level of religious faith. In the sample of employees with the lowest score on religious faith, job insecurity was unrelated to change-oriented behavior $(r=-0.11$, ns).

\section{Discussion}

This study was designed to examine the stress-buffering vs exacerbating effect of religion in the relationship between job insecurity and employee burnout and change-oriented behavior. The hypotheses were tested using a heterogeneous sample 
CDI

19,7

770 of Dutch employees undergoing organizational change. Religion was operationalized as strength of religious faith, without assuming that individuals were of a specific religious denomination. The results indicate that for both burnout and change-oriented behavior, religion exacerbates rather than buffers the negative effects of job insecurity. Specifically, employees with high levels of religious faith suffered more from job insecurity in terms of emotional exhaustion and cynicism than employees with low levels of religious faith. Similarly, when confronted with job insecurity, employees with high levels of religious faith took less initiative and were less willing to comply with organizational changes than employees with low levels of religious faith.

This paper makes a valuable contribution for various reasons. First, our results challenge and extend existing knowledge on the role of religion in coping with life stressors. The dominant view has been that religion is beneficial in coping with major stressors (Park, 2005; Park and Folkman, 1997). The results of our study, however, suggest otherwise: religion had an exacerbating rather than a buffering effect on the relationship between job insecurity and outcomes. The potential threat of losing one's job was more stressful for highly religious employees than for employees with low levels of religiousness. We believe that religion acted as an additional demand on the individuals in our sample. When confronted with material and in particular immaterial losses, like loss of self and sacred purpose, religious employees may experience more strain. We expect that religiousness places so much emphasis on work as a central, social role that it cannot protect individuals when this role is threatened. In this respect, religion does not seem to represent a protection for frustrations about potential job loss. Rather, it functions as an internal demand that individuals experience the pressure to fulfill.

Our findings may be seen as a sign of organized religion's double-edged attitude toward work: while organized religion places a heavy emphasis on work, it does not provide the education and/or tools needed to utilize religious beliefs and practices (e.g. prayer) as a functional coping mechanism at the workplace. It certainly does a good job of providing examples and teaching of how to use religious beliefs and practices in coping with sadness, sickness, death, or other losses, but seems to fall short in demonstrating how to apply these same beliefs, practices and principles in workrelated events (Nash et al., 2001).

About 35 percent of the respondents in our sample had the lowest possible score on religious faith. We conducted an ancillary analysis on respondents with at least minimal levels of religious faith, excluding the group of "atheists." The results were very similar to the main analysis, except for the fact that job insecurity and religious faith did not significantly interact in their prediction of change-oriented behavior. Job insecurity was equally negatively related to change-oriented behavior, independent of whether someone was a "strong" or "weak" believer. In the sample of "nonbelievers," job insecurity was unrelated to change-oriented behavior. This finding hints at the existence of a threshold effect: inimal levels of religious faith are sufficient to turn job insecurity from a neutral stressor into a hindrance stressor. We interpret this finding as supporting our theoretical rationale that for religious people, regardless of their level of religiosity, job insecurity is an identity-threatening stressor, and that therefore religious people react more strongly to job insecurity than do non-religious people; in this case, by lowering their willingness to change and to take initiative.

A second contribution is that in the current study we focussed on the importance of the role that work plays in an individual's self-concept. The results suggest that for religious people, job insecurity and the fear of losing one's job may seriously undermine 
an individual's most salient role-identities. This is particularly true for religious affiliations such as Protestantism and Catholicism. However, work may have a less prominent role in other world religions. Future studies may therefore take into account the importance religions attach to work, as different religions have different life philosophies that might impact the behavior in the various social roles in a different way. Another suggestion is to examine whether religion plays the same exacerbating role for the impact of work stressors other than job insecurity. For example, most world religions include teachings on forgiveness and pro-social behavior. Accordingly, it can be expected that religious people react differently to workplace stressors such as interpersonal conflict, ostracism, and workplace bullying. They may also respond differently to positive workplace experiences such as helping behavior and particular types of positive leadership (e.g. humble and servant leadership). Taken together, this study provides an example of how religion can influence employee reactions to workplace stressors. In addition, it provides the theoretical foundation to examine and understand the role of religion in conjunction with other important workplace phenomena.

Despite the logical appeal of the self-concept explanation, other explanations may also account for the observed findings. For example, it is plausible that religious people have lower levels of perceived control over the situation. Indeed, a large body of research has established links between religiousness and beliefs regarding control (e.g. Rothbaum et al., 1982; Wong-McDonald and Gorsuch, 2000). Some religions, including Christianity, explicitly encourage adherents to surrender control and hand over control to powerful others (Exline, 2002). An alternative explanation to our finding could therefore be that religiousness accelerates the effects of job insecurity because religious people feel even more powerless than do non-religious people.

Third, we extended the nomological network of job insecurity by examining its main effects on change-oriented behaviors. Abundant evidence already exists on the negative health impact of job insecurity (Cheng and Chan, 2008; Sverke et al., 2002), a finding that is corroborated by the present study. However, there is a scarcity of research that examines the relationship between job insecurity and change-oriented behaviors. The results from this study showed that job insecure employees were less likely to support organizational changes, which aligns with the idea that feelings of uncontrollability caused by job insecurity lead employees to behaviorally withdraw from the situation (Jordan et al., 2002). Not surprisingly, job insecure employees were not supportive of the change initiatives that caused the threat of job loss. This poses a particular challenge to managers and change consultants alike: How to actively involve employees who feel insecure and get their ideas out to make the change process more effective when people, because of the change, are reluctant to comply with the changes? We find ourselves in a Catch-22 situation for which the current state of research does not provide a conclusive solution. In order to get out of the stalemate, job insecurity scholars should focus more on examining relationships with proactive behaviors, such as voice, issue selling, and change organizational citizenship behavior, and on the conditions under which the paralyzing effect of job insecurity is less pronounced.

\section{Limitations and future research directions}

Several limitations of this study need to be noted. First, it is important to recognize that our study relied on a cross-sectional survey design. As a result, we cannot make any definite inferences about causality. Longitudinal studies are particularly needed to demonstrate causation.

\section{Religiousness in times of job insecurity}

771 
CDI

19,7

772
Second, all data consisted of self-reported measures, meaning that part of the found relations could be due to common method variance (Podsakoff et al., 2003). However, self-reports are justifiable and probably even necessary when studying constructs that are self-referential respondent perceptions, such as job insecurity, burnout and religious faith (Chan, 2009). We took several a priori measures to mitigate common-method bias (Conway and Lance, 2010; Podsakoff et al., 2003), including the use of construct-valid measurement scales, and following the recommendations for questionnaire design (e.g. protecting respondent anonymity, instructing respondents that are no right or wrongs answers). In addition, the expected measurement model provided a slightly better fit to the data than alternative models did (i.e. a model in which all items loaded on a single factor; a model in which the items loaded on both their expected factors and a latent common method factor). Although it cannot ruled out that common-method bias to some extent contributed to the significant correlations, it does not seem to pose a serious threat to the interpretation of the results from this study.

Third, it would be fruitful in future research to obtain a more complete operationalization of religion. In particular, researchers might consider using the faith at work scale (Lynn et al, 2009), which measures the extent to which individuals believe they can utilize their spiritual capital at work. In doing so, one could investigate whether spirituality exacerbates the negative effect of job insecurity in the same way as religiosity does. Another possible scale is a measure of sanctification developed by Pargament and Mahoney (1999). In addition, it would be interesting to obtain actual measures of work as a central life interest in order to determine whether or not religious people attach more value to work than do less or non-religious people (e.g. job involvement, work centrality; Paullay et al., 1994). These measures may help bolster our claim that highly religious people place their work in a higher hierarchy of life priorities and therefore suffer more from job insecurity than do less religious people. As is, we can only speculate that holding work in a more sacred light for religious people explains the observed interaction effect.

Fourth, our sample mainly consisted of Catholic and Protestant employees from Belgium and the Netherlands. Therefore some caution is warranted in generalizing our results to other religious affiliations and communities, and to other cultures and nationalities. Future studies could include workers from more diverse religious backgrounds and investigate to what extent religious affiliation influences the relationships between the work environment, religious faith, and employee outcomes. Future studies could also consider additional known outcomes of job insecurity to determine whether current results can be replicated when considering other outcomes (e.g. job satisfaction, organizational commitment, physical/mental health, turnover intentions, and safety).

Finally, future studies could include the role of religion in coping with actual job loss as opposed to job insecurity, perhaps through a longitudinal study in an organization that is downsizing. It may be that differential results would be found when comparing the threat or anticipation of a stressful event (job insecurity) to the appraisal of the occurrence of a stressful event. Most of the literature on the buffering hypothesis of religion has focussed on the latter case of actual events. Therefore, perhaps religion does help to cope with the negative impact of stressful events after they have happened, (e.g. in terms of acceptance), but, as our study shows, it is not successful in buffering the negative impact of the anticipated stressful events.

\section{Conclusion}

Although previous scholars have theorized about the role of religion in reactions to job insecurity (e.g. Probst and Strand, 2010; Zellars et al., 2003), to date there has been 
no empirical test of these propositions. In our study, we reviewed theoretical arguments suggesting religion could be characterized as either a demand or a resource and developed corresponding hypotheses regarding how this might lead to religion acting as a buffering or as an exacerbating force in employee reactions to job insecurity. Despite the intuitive appeal of religion as a buffer against the negative impact of stressors, the results of the current study provided evidence to the contrary and in support of the stress-exacerbating hypothesis. Despite these initial intriguing results, additional research is needed to investigate the specific explanatory mechanisms behind this pattern of results.

\section{Note}

1. We also carried out a moderated regression analysis using ordinary least squares. The results were identical in terms of strength and direction of the effects.

\section{References}

Argyle, M. (2000), Psychology and Religion: An Introduction, Routledge, London.

Bauer, D.J. and Curran, P.J. (2005), "Probing interactions in fixed and multilevel regression: inferential and graphical techniques", Multivariate Behavioral Research, Vol. 40 No. 3, pp. 373-400.

Bernhard-Oettel, C., De Cuyper, N., Schreurs, B. and De Witte, H. (2011), "Linking job insecurity to well-being and organizational attitudes in Belgian workers: the role of security expectations and fairness", International Iournal of Human Resource Management, Vol. 22 No. 9, pp. 1866-1886.

Berntson, E., Naswall, K. and Sverke, M. (2010), "The moderating role of employability in the association between job insecurity and exit, voice, loyalty and neglect", Economic and Industrial Democracv, Vol. 31 No. 2, pp. 215-230.

Bornstedt, G.W. and Marwell, G. (1978), "The reliability of the products of two random variables", in Schuessler, K.F. (Ed.), Sociological Methodology, Iossev-Bass, San Francisco, CA, pp. 254-273.

Bosman, J., Buitendach, J.H. and Laba, K. (2005), "Job insecurity, burnout and organisational commitment among employees of a financial institution in Gauteng", SA Journal of Industrial Psychology, Vol. 31 No. 4, pp. 32-40.

Boswell, W.R., Olson-Buchanan, J.B. and Harris, T.B. (in press), "I cannot afford to have a life: employee adaptation to feelings of job insecurity", Personnel Psychology, doi:10.1111/ peps.1261.

Brewer, E.W. and Shapard, L. (2004), "Employee burnout: a meta-analysis of the relationship between age or years of experience", Human Resource Development Review, Vol. 3 No. 2, pp. 102-123.

Browne, M.W. and Cudeck, R. (1993), "Alternative ways of assessing model fit”, in Bollen, K.A. and Long, J.S. (Eds), Testing Structural Equation Models, Sage, Beverly Hills, CA, pp. 136-162.

Catalano, R., Rook, K. and Dooley, D. (1986), "Labor markets and help-seeking: a test of the employment security hypothesis", Journal of Health and Social Behavior, Vol. 27 No. 3, pp. 277-287.

Chan, D. (2009), "So why ask me? Are self-report data really that bad", in Lance, C.E. and Vandenberg, R.J. (Eds), Statistical and Methodological Myths and Urban Legends: Doctrine, Verity and Fable in the Organizational and Social Sciences, Routledge, New York, NY, pp. 309-336. 
CDI

19,7

774
Cheng, G.H.L. and Chan, D.K.S. (2008), "Who suffers more from job insecurity? A meta-analytic review", Applied Psychology: An International Review, Vol. 57 No. 2, pp. 272-303.

Choi, J.N. (2007), "Change-oriented organizational citizenship behavior: effects of work environment characteristics and intervening psychological processes", Lournal of Organizational Behavior, Vol. 28 No. 4, pp. 467-484.

Conway, J.M. and Lance, C.E. (2010), "What reviewers should expect from authors regarding common method bias in organizational research", Iournal of Business and Psvchologv, Vol. 25, No. 3, pp. 325-334.

Cortina, J.M., Chen, G. and Dunlap, W.P. (2001), “Testing interaction effects in LISREL: examination and illustration of available procedures", Organizational Research Methods, Vol. 4 No. 4, pp. 324-360.

Davy, J.A., Kinicki, A.J. and Scheck, C.L. (1997), "A test of job security's direct and mediated effects on withdrawal cognitions", Iournal of Organizational Behavior, Vol. 18 No. 4, pp. 323-349.

De Cuyper, N. and De Witte, H. (2007), "Job insecurity in temporary versus permanent workers: associations with attitudes, well-being, and behaviour", Work \& Stress, Vol. 21 No. 1, pp. 65-84.

De Cuyper, N., Mäkikangas, A., Kinnunen, U., Mauno, S. and De Witte, H. (2012), “Cross-lagged associations between perceived external employability, job insecurity, and exhaustion: testing gain and loss spirals according to the conservation of resources theory", $\underline{\text { Dournal of }}$ Organizational Behavior, Vol. 33 No. 6, pp. 770-788.

Dekker, S.W.A. and Schaufeli, W.B. (1995), "The effects of job insecurity on psychological health and withdrawal: a longitudinal study", Australian Psychologist, Vol. 30 No. 1, pp. 57-63.

Demerouti, E., Bakker, A.B., Nachreiner, F. and Schaufeli, W.B. (2001), "The job demandsresources model of burnout", Lournal of Applied Psvchology, Vol. 86 No. 3, pp. 499-512.

De Witte, H. (2000), "Arbeidsethos en jobonzekerheid: meting en gevolgen voor welzijn, tevredenheid en inzet op het werk (Work ethic and job insecurity: assessment and consequences for wellbeing, satisfaction and performance at work)", in Bouwen, R., De Witte, K., De Witte, H. and Taillieu, T. (Eds), Van Groep Naar Gemeenschap (From Group to Community), Garant, Leuven, pp. 325-350.

De Witte, H. (1999), "Job insecurity and psychological well-being: review of the literature and exploration of some unresolved issues", European Journal of Work and Organizational Psychology, Vol. 8 No. 2, pp. 155-177.

Dezutter, J., Robertson, L.A., Luyckx, K. and Hutsebaut, D. (2010), "Life satisfaction in chronic pain patients: the stress-buffering role of the centrality of religion", Journal for the Scientific Studv of Religion, Vol. 49 No. 3, pp. 507-516.

Ellison, C.G. and Levin, J.S. (1998), "The religion-health connection: evidence, theory, and future directions", Health Education \& Behavior, Vol. 25 No. 6, pp. 700-720.

Emmons, R.A. (2000), "Is spirituality an intelligence? Motivation, cognition, and the psychology of ultimate concern", The International Journal for the Psychology of Religion, Vol. 10 No. 1, pp. 3-26.

Emmons, R.A. and Paloutzian, R.F. (2003), “The psychology of religion”, Annual Review of Psvchology, Vol. 54 No. 1, pp. 377-402.

Exline, J.J. (2002), "Stumbling blocks on the religious road: fractured relationships, nagging vices, and the inner struggle to believe", Psychological Inquiry, Vol. 13 No. 3, pp. 182-189.

Faugier, J. and Sargeant, M. (1997), "Sampling hard to reach populations", Lournal of Advanced Nursing, Vol. 26 No. 4, pp. 790-797. 
Feather, N.T. and Rauter, K.A. (2004), "Organizational citizenship behaviours in relation to job status, job insecurity, organizational commitment and identification, job satisfaction and work values", Iournal of Occupational and Organizational Psychology, Vol. 77 No. 1, pp. 81-94.

Ferrie, J.E., Shipley, M.J., Stansfeld, S.A. and Marmot, M.G. (2002), "Effects of chronic job insecurity and change in job security on self reported health, minor psychiatric morbidity, physiological measures, and health related behaviours in British civil servants: the Whitehall II study", Iournal of Esidemiologv and Communitv Health, Vol. 56 No. 6, pp. $450-454$.

Ferrie, J.E., Shipley, M.J., Newman, K., Stansfeld, S.A. and Marmot, M. (2005), "Self-reported job insecurity and health in the Whitehall II study: potential explanations of the relationship", Social Science \& Medicine, Vol. 60 No. 7, pp. 1593-1602.

Frese, M., Fay, D., Hilburger, T., Leng, K. and Tag, A. (1997), "The concept of personal initiative: operationalization, reliability and validity in two German samples", Journal of Occubational and Organizational Psychology, Vol. 70 No. 2, pp. 139-161.

Goodman, L.A. (1961), "Snowball sampling”, Annals of Mathematical Statistics, Vol. 32 No. 1, pp. $148-170$.

Hu, L.T. and Bentler, P.M. (1999), "Cutoff criteria for fit indexes in covariance structure analysis: conventional criteria versus new alternatives", Structural Equation Modeling: $A$ Multidisciplinary Journal, Vol. 6 No. 1, pp. 1-55.

Jacobson, D. (1991), "Toward a theoretical distinction between the stress components of the job insecurity and the job loss experiences", Research in the Sociology of Organizations, Vol. 9 No. 1, pp. 1-19.

Jahoda, M. (1982), Employment and Unemployment: A Social-Psychological Analysis, Press Syndicate of the University of Cambridge, New York, NY.

Jordan, P.J., Ashkanasy, N.M. and Hartel, C.E. (2002), "Emotional intelligence as a moderator of emotional and behavioral reactions to job insecurity", Academv of Management Review, Vol. 27 No. 3, pp. 361-372.

Kalyal, H.J., Berntson, E., Baraldi, S., Naswall, K. and Sverke, M. (2010), "The moderating role of employability on the relationship between job insecurity and commitment to change", Economic and Industrial Democracy, Vol. 31 No. 3, pp. 327-344.

Kendler, K.S., Gardner, C.O. and Prescott, C.A. (1997), "Religion, psychopathology, and substance use and abuse: a multimeasure, genetic-epidemiologic study", American Iournal of Psvchiatrv, Vol. 154 No. 3, pp. 322-329.

King, J.E. (2000), "White-collar reactions to job insecurity and the role of the psychological contract: implications for human resource management”, Human Resource Management, Vol. 39 No. 1, pp. 79-92.

Krause, N. (1998), "Neighborhood deterioration, religious coping, and changes in health during late life", The Gerontologist, Vol. 38 No. 6, pp. 653-664.

Lazarus, R.S. (1966), Psychological Stress and the Coping Process, McGraw Hill, New York, NY.

Lazarus, R.S. and Folkman, S. (1984), Stress, Appraisal, and Coping, Springer Publishing Company, New York, NY.

Lim, V.K.G. (1996), "Job insecurity and its outcomes: moderating effects of work-based and nonwork-based social support", Human Relations, Vol. 49 No. 2, pp. 171-194.

Lynn, M.L., Naughton, M.J. and Vander Veen, S. (2009), "Faith at work scale (FWS): justification, development, and validation of a measure of Judaeo-Christian religion in the workplace", Journal of Business Ethics, Vol. 85 No. 2, pp. 227-243.

\section{Religiousness in times of job insecurity}

775 
CDI

19,7

776

MacCallum, R.C., Browne, M.W. and Sugawara, H.M. (1996), "Power analysis and determination of sample size for covariance structure modeling", Psychological Methods, Vol. 1 No. 2, pp. 130-149.

Maslach, C., Jackson, S.E. and Leiter, M.P. (1986), Maslach Burnout Inventory - Manual, 3rd ed., Consulting Psychologists Press, Palo Alto, CA.

Maslach, C., Schaufeli, W.B. and Leiter, M.P. (2001), "Job burnout”, Annual Review of Psvchologv, Vol. 52 No. 1, pp. 397-422.

Mathieu, J.E., Tannenbaum, S.I. and Salas, E. (1992), "Influences of individual and situational characteristics on measures of training effectiveness", Academv of Management Journal, Vol. 35 No. 4, pp. 828-847.

Metselaar, E.E. (1997), Assessing the Willingness to Change: Construction and Validation of the DINAMO, Vrije Universiteit Amsterdam, Amsterdam.

Mickley, J.R., Pargament, K.I., Brant, C.R. and Hipp, K.M. (1998), "God and the search for meaning among hospice caregivers”, Hospice Iournal, Vol. 13 No. 4, pp. 1-17.

Nash, L.L., McLennan, S. and Blanchard, K.H. (2001), Church on Sunday, Work on Monday: The Challenge of Fusing Christian Values with Business Life, Jossey-Bass, San Francisco, CA.

Näswall, K., Sverke, M. and Hellgren, J. (2005), “The moderating role of personality characteristics on the relationship between job insecurity and strain”, Work \& Stress, Vol. 19 No. 1, pp. 37-49.

Pargament, K.I. (1997), The Psychology of Religious Coping: Theory, Research, Practice, Guilford Press, New York, NY.

Pargament, K.I. (1999), “The psychology of religion and spirituality? Yes and no”, The International Journal for the Psychology of Religion, Vol. 9 No. 1, pp. 3-16.

Pargament, K.I. (2002), "The bitter and the sweet: an evaluation of the costs and benefits of religiousness", Psychological Inquiry, Vol. 13 No. 3, pp. 168-181.

Pargament, K.I. and Mahoney, A. (1999), "Spirituality: discovering and conserving the sacred", in Snyder, C.R. (Ed.), Handbook of Positive Psychology, Oxford University Press, New York, NY.

Pargament, K.I., Smith, B.W., Koenig, H.G. and Perez, L. (1998), "Patterns of positive and negative religious coping with major life stressors", Iournal for the Scientific Studv of Religion, Vol. 34 No. 4, pp. 710-724.

Park, C.L. (2005), "Religion as a meaning-making framework in coping with life stress", $\underline{\text { Journal of }}$ Social Issues, Vol. 61 No. 4, pp. 707-729.

Park, C.L. and Cohen, L.H. (1993), "Religious and nonreligious coping with the death of a friend", Cognitive Therapy and Research, Vol. 17 No. 6, pp. 561-577.

Park, C.L. and Folkman, S. (1997), "Meaning in the context of stress and coping", Review of General Psychology, Vol. 1 No. 2, pp. 115-144.

Paullay, I.M., Alliger, G.M. and Stone-Romero, E.F. (1994), "Construct validation of two instruments designed to measure job involvement and work centrality", Iournal of Applied Psychology, Vol. 79 No. 2, pp. 224-228.

Plante, T.G. and Boccaccini, M.T. (1997), "The santa clara strength of religious faith questionnaire”, Pastoral Psvchology, Vol. 45 No. 5, pp. 375-387.

Plante, T.G., Vallaeys, C.L., Sherman, A.C. and Wallston, K.A. (2002), "The development of a brief version of the santa clara strength of religious faith questionnaire", Pastoral Psychology, Vol. 50 No. 5, pp. 359-368. 
Podsakoff, P.M., MacKenzie, S.B., Lee, J.Y. and Podsakoff, N.P. (2003), "Common method biases in behavioral research: a critical review of the literature and recommended remedies", Lournal of Applied Psychology, Vol. 88 No. 5, pp. 879-903.

Podsakoff, P.M., MacKenzie, S.B., Paine, J.B. and Bachrach, D.G. (2000), "Organizational citizenship behaviors: a critical review of the theoretical and empirical literature and suggestions for future research", Lournal of Management, Vol. 26 No. 3, pp. 513-563.

Probst, T.M. (2000), "Wedded to the job: moderating effects of job involvement on the consequences of job insecurity", Journal of Occubational Health Psvchology, Vol. 5 No. 1, pp. 63-73.

Probst, T.M. (2005), "Countering the negative effects of job insecurity through participative decision making: lessons from the demand-control model", Iournal of Occupational Health Psychology, Vol. 10 No. 4, pp. 320-329.

Probst, T.M., Barbaranelli, C. and Petitta, L. (2013), "The relationship between job insecurity and accident under-reporting: a test in two countries", Work \& Stress, Vol. 27 No. 4, pp. 383-402.

Probst, T.M., Stewart, S., Gruys, M.L. and Tierney, B.W. (2007), "Productivity, counterproductivity, and creativity: the ups and downs of job insecurity", Ioumal of Occupational and Organizational Psvchologv, Vol. 80 No. 3, pp. 479-497.

Probst, T.M. and Strand, P. (2010), "Perceiving and responding to job insecurity: a workplace spirituality perspective", Iournal of Management. Stiritualitv and Religion, Vol. 7 No. 2, pp. 135-156.

Reisel, W.D., Chia, S.L., Maloles, C.M. and Slocum, J.W. (2007), "The effects of job insecurity on satisfaction and perceived organizational performance", Lournal of Leadership \& Organizational Studies, Vol. 14 No. 2, pp. 106-116.

Rosenblatt, Z. and Ruvio, A. (1996), "A test of a multidimensional model of job insecurity: the case of Israeli teachers", Lournal of Organizational Behavior, Vol. 17 No. 1, pp. 587-605.

Roskies, E., Louis-Guerin, C. and Fournier, C. (1993), "Coping with job insecurity: how does personality make a difference?", Iournal of Organizational Behavior, Vol. 14 No. 7, pp. 617-630.

Rothbaum, F., Weisz, T.R. and Snyder, S.S. (1982), "Changing the world and changing the self: a two-process model of perceived control", Lournal of Personality and Social Psvchologv, Vol. 42 No. 1, pp. 5-37.

Schaefer, F.C., Blazer, D.G. and Koenig, H.G. (2008), "Religious and spiritual factors and the consequences of trauma: a review and model of the interrelationship", International Iournal of Psychiatrv in Medicine, Vol. 38 No. 4, pp. 507-524.

Schaufeli, W.B., Leiter, M.P., Maslach, C. and Jackson, S.E. (1996), "Maslach burnout inventory general survey", in Maslach, C., Jackson, S.E. and Leiter, M.P. (Eds), The Maslach Burnout Inventory: Test manual, 3rd ed., Consulting Psychologists Press, Palo Alto, CA, pp. 22-26.

Schaufeli, W.B. and Taris, T.W. (2005), "The conceptualization and measurement of burnout: common ground and worlds apart", Work \& Stress, Vol. 19 No. 3, pp. 256-262.

Schreurs, B., van Emmerik, H., Notelaers, G. and De Witte, H. (2010), "Job insecurity and employee health: the buffering potential of job control and job self-efficacy", Work \& Stress, Vol. 24 No. 1 , pp. 56-72.

Smelser, N.J. and Baltes, P.B. (2001), International Encyclopedia of the Social \& Behavioral Sciences, Elsevier, Amsterdam.

Staufenbiel, T. and König, C.J. (2010), "A model for the effects of job insecurity on performance, turnover intention, and absenteeism", Iournal of Occupational and Organizational Psychology, Vol. 83 No. 1, pp. 101-117.

Staw, B.M., Sandelands, L.E. and Dutton, J.E. (1981), "Threat rigidity effects in organizational behavior: a multilevel analysis", Administrative Science Quarterly, Vol. 26 No. 4, pp. 501-524. 
CDI

19,7

778

Steptoe, A., Cropley, M. and Joekes, K. (1999), "Job strain, blood pressure and response to uncontrollable stress", Journal of Hypertension, Vol. 17 No. 2, pp. 193-200.

Sverke, M., Hellgren, J. and Näswall, K. (2002), "No security: a meta-analysis and review of job insecurity and its consequences", Journal of Occupational Health Psychologv, Vol. 7 No. 3, pp. 242-264.

Thoits, P.A. (1991), "On merging identity theory and stress research”, Social Psychology Quarterlv, Vol. 54 No. 2, pp. 101-112.

van den Heuvel, M., Demerouti, E., Schreurs, B., Bakker, A.B. and Schaufeli, W.B. (2009), "Does meaning-making help during organizational change? Development and validation of a new scale", Career Development International, Vol. 14 No. 6, pp. 508-533.

Vander Elst, T., De Cuyper, N. and De Witte, H. (2011), "The role of perceived control in the relationship between job insecurity and psychosocial outcomes: moderator or mediator?", Stress and Health, Vol. 27 No. 3, pp. e215-e227.

Wallin, P. and Clark, A.L. (1964), "Religiosity, sexual gratification, and marital satisfaction in the middle years of marriage", Social Forces, Vol. 42 No. 3, pp. 303-309.

Westman, M., Etzion, D. and Danon, E. (2001), "Job insecurity and crossover of burnout in married couples", Lournal of Organizational Behavior, Vol. 22 No. 5, pp. 467-481.

Wiesenfeld, B.M., Brockner, J., Petzall, B., Wolf, R. and Bailey, J. (2001), "Stress and coping among layoff survivors: a self-affirmation analysis", Anxietv. Stress and Coping, Vol. 14 No. 1, pp. 15-34.

Wong-McDonald, A. and Gorsuch, R.L. (2000), "Surrender to god: an additional coping style?", Journal of Psychology and Theology, Vol. 28 No. 2, pp. 149-161.

Zapata-Phelan, C., Colquitt, J., Scott, B. and Livingston, B. (2009), "Procedural justice, interactional justice, and task performance: the mediating role of intrinsic motivation”, Organizational Behavior and Human Decision Processes, Vol. 108 No. 1, pp. 93-105.

Zellars, K.L., Perrewe, P.L. and Bree, J.R. (2003), "The multiple roles of spirituality in occupational stress, and psychological well-being”, in Giacalone R.A. and Jurkiewicz C.L. (Eds), The Handbook of Workplace Spirituality and Organizational Performance, M.E. Sharpe, New York, NY, pp. 300-313.

Zheng, X., Diaz, I., Tang, N. and Tang, K. (2014), "Job insecurity and job satisfaction: the interactively moderating effects of optimism and person-supervisor deep-level similarity", Career Develobment International, Vol.19 No. 4, pp. 426-446.

Zinnbauer, B.J., Pargament, K.I. and Scott, A.B. (1999), "The emerging meanings of religiousness and spirituality: problems and prospects", Journal of Personality, Vol. 67 No. 6, pp. 889-919.

Zinnbauer, B.J., Pargament, K.I., Cole, B., Rye, M.S., Butter, E.M., Belavich, T.G., Hipp, K.M., Scott, A.B. and Kadar, J.L. (1997), "Religion and spirituality: unfuzzying the fuzzy", Journal for the Scientific Study of Religion, Vol. 36 No. 4, pp. 549-564.

\section{Corresponding author}

Dr Bert Schreurs can be contacted at: B.SCHREURS@MAASTRICHTUNIVERSITY.NL

To purchase reprints of this article please e-mail: reprints@emeraldinsight.com Or visit our web site for further details: www.emeraldinsight.com/reprints 